\title{
Teacher Strategy to Prevent Bullying for Special-Need Student in Inclusive School at Australian Independent School in Academic Year 2020
}

\author{
Ni Luh Ayu Juniarti \\ Prodi Pendidikan Bahasa Inggris, FKIP, Universitas Dwijendra \\ E-mail: ayutirta2011@gmail.com \\ I Komang Dedik Susila \\ Prodi Pendidikan Bahasa Inggris, FKIP, Universitas Dwijendra \\ E-mail: dediksusila@gmail.com
}

\begin{abstract}
Abstrak
Peserta didik anak berkebutuhan khusus dekat dengan bullying bahkan di sekolah. Guru yang menangani anak berkebutuhan khusus harus memiliki suatu strategi untuk mencegah terjadinya bullying. Penelitian ini bertujuan untuk menganalisa dari strategi guru untuk mencegah bullying terhadap anak berkebutuhan khusus di sekolah inklusi di Australian Independent School (AIS) pada tahun akademik 2020. Penelitian ini merupakan penelitian kualitatif studi kasus pada strategi guru dalam mencegah bullying. Data diperoleh dari observasi, rekaman, dokumen, analisa dan wawancara. Data kemudian di analisis secara kualitatif dengan metode analisis dari Miles dan Huberman (1994). Hasil dari penelitian ini menunjukkan bahwa guru memberdayakan para peserta didik dengan pengetahuan dan akibat dari bullying melalui beberapa metode seperti management kelas, keterlibatan moral, promosi Up-stander dan By-stander, penghargaan, dan pelatihan terhadap staff. Penerapan strategi tersebut berkontribusi positif dalam pencegahan bullying di Australian Independent School (AIS).
\end{abstract}

Kata kunci: Peserta didik berkebutuhan khusus, bullying, strategi guru.

\begin{abstract}
Special-need students are close to bullying even in school. Teachers dealing with special-need students must have strategies to prevent bullying. This study aimed at analyzing of teachers' strategies to prevent bullying for special-need student in inclusive school at Australian Independent School (AIS) in the academic year 2020. This study was a qualitative study in the form of phenomenon on teacher's strategies to prevent bullying. The data were collected through observation, recording, document, analyzing, and interview. The data were analyzed using triangulation methodological. The findings showed that the teacher empower the student with the knowledge about bullying and the effect of bullying through several method namely classroom method, moral engagement, promoting Up-stander and By-Stander program, rewarding and training staff. It can be concluded that the teacher of Australian Independent School has successfully implemented anti-bullying program.
\end{abstract}

Keywords: special need student, bullying, teacher's strategy

\section{INTRODUCTION}

Education aims at developing behavior and character of a child in order to adjust themselves in their living neighborhood (Lestari, Yusmansyah, \& Mayasari, 2018). The most important value is character education that could apply norms and accept differences in student daily life, which also could create good habits, therefore educational institutions are expecting to realize an excellent and independent characteristic of their student. According to the World Health Organization (WHO), there are three main categories of special-need. They are physical disabilities (multiple sclerosis, allergies and asthma, juvenile arthritis, leukemia, muscular dystrophy, epilepsy), developmental (down syndrome, autism, dyslexia, visual processing disorder) behavioral/emotional (obsessive disorder, 
anxiety, bipolar; sensory-impaired such as blindness, deaf or limited hearing, visual impaired). Special need people are very often to get discrimination on their everyday life. The discrimination is like as underestimating, stupidity, and bullying.

According to Olwus and Limber (2010), bullying is a specific form of aggressive behavior and can be described as a situation when a student is exposed repeatedly and over time, to negative actions on the part of one or more students. In inclusive school the issue of bullying is mostly appearing even through direct or indirect. Desiningrum (2016) states that a special-need child is a child that has disabilities those intersect with the normal and a normal which does not appear during developmental phase. Special-need students are a child that has some disabilities in physical, emotional, intellectual, and socialization and have the right to earn an education with a modified curriculum based on their individual characteristics and needs to optimize potential. Padmadewi and Artini (2017) state that inclusion school is a school that includes students with different conditions, backgrounds and abilities in the same classroom and brings an atmosphere that will reserve every individual feeling with respect, acceptance and the sense of belonging. Inclusion schools are one's of the form of equality and has been design to decrease discrimination for special need student to earn an equal education.

Australian Independent School (AIS) is one of the international schools in Bali that has an inclusive class for special-need students. It is urgent to prevent bullying that always happens and become an issue to special-need students. Besides, other schools have a lack of information to prevent bullying. Thus, this research is necessary to provide information to deal with or even prevent bullying. It was focused on analyzing the teacher strategies to prevent bullying in class and all school communities in AIS Bali.

Bullying is a form of obvious and aggressive behavior to those teased, assaulted (verbal or physically) that intend to avoid and rejected from their peers (Beane, 2009). These days, in our own society has developed the habit that educated students get angrily, talking in rude, cursing and snapped to other students with the word that actually treating or even impolite their own teacher. Nicknamed is often given to discriminate and humiliate a special need and make them different among the others. These nicknames are given to show the weakness of the disabilities and this name is usually given by the person that is near or relative. Bullying anticipation not only by parents, school and neighborhood supervision thus also needs to appear inside of special-need students itself. The research result indicated that bullying to autism students still happened. The forms of bullying which were often experienced by autism students were bullying physical and verbal. The bullying performer to autism students was the regular student who a friend of the autism student. The teachers in inclusion elementary school had perceptual bullying to autism children as behavior disturbing and making the autism students uncomfortable. The prevention experienced by the school was the lack of educators for autism students causing the bullying.

The prevention experienced by the school was the lack of educators for autism students causing the bullying. Bullying could be solved by giving comprehension to regular students that 
bullying was bad behavior, approaching to autism students, and often involving the autism students in the school activity. The result of this study is expected to provide positive contribution to theoretical insight in strategies to prevent bullying for special need students. The result of this study is expected to be useful for teachers as beneficial information about the teacher strategy in preventing bullying for special-need students in inclusive school. The aim of this study is to found out student responded towards strategies preventing bullying for special-need students in inclusive school at Australian Independent School in the academic year of 2020 .

\section{METHODOLOGY}

The subjects of this study were the teachers of special-need students inside their classes of Australian Independent School in the academic year 2020. They can represent the strategies to prevent bullying to special-need students of teachers of AIS. The teacher with a special-need student inside their class will have discussion with the psychiatrist, speaking expert and counselor that the school has in every semester. The expert will observe the special-need student to find out their development and make a dialogue with the student of their feelings. Thus, the teachers perform a technique to prevent bullying to provide a safe classroom for special-need students.

The design of this study was a qualitative study in the form of phenomenology. According to Putra (2012), that phenomenology research is a fundamental criticism to the oldest philosophy and has the quality of radical, on the other way to phenomenology to say critics of radicalism and empires'. This study analyzed the teacher strategies in preventing bullying for special-need students in inclusive schools at Australian Independent School in the academic year 2020 .

This study was conducted at Australian Independent School in the academic year 20120. The research was conducted in three classes; foundation, year 3 and year 10. The selection of AIS as the setting of study will determine because AIS is the one of an inclusive school that combines between mainstream students and special-need students in Denpasar and the writer has been given access to conduct the research in these several classes. Data of this study are collected by through interview and observation using several instruments, namely the interview guide and field note. The data collected were analyzed qualitatively using Miles and Huberman (1994) theory of data analysis which consisted of data collection, data reduction, data display, and conclusion drawing/ verification.

\section{FINDING AND DISCUSSION}

This study intended to discuss the teacher's strategy to prevent bullying of specialneed students in inclusive school at Australian Independent School in the academic year of 2020. The section reports the finding of teacher strategies to prevent bullying, namely classroom management,

\section{a. Classroom Management}

A Classroom is a place that can be access by teacher and student to do the learning and teaching process. To manage this all in wellorganized the teacher must have knowledge about classroom management. Before bringing the education into the classroom, some teachers need 
to manage their classroom to become the environment that is interesting, attractive, secure and safe every student to be ready to receive the knowledge transfer from their teacher. There are several efforts from a teacher to create and maintain and become an effective classroom, which are (1) understand the factors that can support the learning and teaching process, (2) understand the problem that can be predicted and might be grow and break the teaching and learning process, and (3) understand as many as approach method in classroom management and choose the right method or problem solving.

Based on the observation, to create a save atmosphere inside the classroom, the teacher has adopted several methods and apply it in their combined class. The first method was control approach method. This method is as the process or controlling student behavior. The role of teacher is to create and maintain disciplinary situation in classroom. Based on the observation inside the classroom, the researcher found that the teacher has adopted the classroom management authoritative style during their activity. The purpose of classroom management is to maintain student behavior and increasing the student academic engagement. Classroom management also could decrease negative behaviors and increases time spent academically engaged. The student can do a class discussion and give their positive feedback of their own opinion of a subject. Based on the interview with the teacher, to create a safe atmosphere the teacher has placed some regulation in front of the classroom on the wall. The specialneed student also introduced with the class rules to maintain their emotional behavior. These processes were thought rapidly by the learning support of the special-need teacher through several activities that ease understands by them.

The second method that the teacher has been adopted is freedom of management approach. This method is interpreted in a process to help student feel free to do something anytime anywhere. The special need students are given a special corner in the class or them to maintain their emotional moods and can absorb the material freely. Teacher are also need to develop good student behavior in preventing the first stage of bullying, they have departed the point of behavioral psychology. Based on interviewed the teacher, to prevent and remain students about the effect of bullying among the students the teacher also places some posters inside the classroom, the posters have been designed in color that could attract students to take a look and ease to be understood.

The third method that the teacher adopted is social emotional approach. This approach will be achieved maximally in good interpersonal relation develop in the classroom. Therefore, the teacher should develop a good classroom climate through maintain positive relation between mainstream students and special need student by understanding attitude and nurturing or protective attitude. Building the student characters are also the goals of a teacher in organizing their classroom. Australian curriculum has also recommended every teacher to insert the values of Australian Schooling during teaching and learning activity. The teacher all would have circle time discussion, which brings students, teacher and school professionals to address the issue of bullying and explore the effect of bulling when problems arise. Teachers have placed the emphasized content in the classroom that could be seen as an important component 
within the framework to develop social and emotional competencies.

\section{b. Learning Resources}

As an international school, Australian Independent Schools are implemented Australian Curriculum from ACARA. This curriculum is designed to help all young Australian and the world to become successful learners, confident and creative individuals and active and informed citizens. According to Usman and Dangara (2016) stated that a good education could not be effective without putting in place certain mechanisms and requires a provision of resources. The character education reflected on their vision which is to make their graduates to become confident, capable and socially aware in global citizen. Since bullying is the most important issue, the teacher prepared the planning based on a lesson plan to conduct the teaching and learning process to prevent bullying inside the school. implementation of learning and can increase students' motivation to learn so that later it will affect student learning outcomes (Priantini,2019).

The special-need student also has their own lesson planning that prepared by the learning support teacher and class teacher based on their needs. This lesson plans are called Individualized Education Plan (IEP). The IEP preparation is also conducted with leader of learning support teacher. The learning support teacher has conducted meeting with the parents, class teachers also head of school about the student behavior, the level of learning that the student will be improved. In this research, the researcher analyzed the teacher lesson plan for the subject of "Health and Physical Education" in term 2 on year 4 classrooms, a term is divided into 10 weeks. Health and Physical education are one of the lesson subjects taught to the student to develop knowledge, understanding and skills to support them to be resilient, to develop a strong sense of self, to develop health literacy competencies in order to enhance their own and others' health and wellbeing. The subject lesson also includes the character education including the value of human beings starting in their family, to their friends and bigger society and also different cultures that the student will be part of. The diversity and bullying sub-subject are to be taught in week 3 until week 6 of the school calendar. In the design of this lesson plan the teacher used the health book as the guidance as well as ACARA as the syllabus. 


\begin{tabular}{|c|c|c|c|c|c|}
\hline Week & Focus with AC number & Resources & Activities & Assessment Tasks & Differentiation \\
\hline 3 & $\begin{array}{l}\text { Diversity, the spice of life } \\
\text { Describe how respect, } \\
\text { empathy and valuing diversity } \\
\text { can positively influence } \\
\text { relationships (ACPPSO37). }\end{array}$ & $\begin{array}{l}\text { Australian Curriculum } \\
\text { Health Year } 4 \text { book } \\
\text { (p47) } \\
\text { Online links }\end{array}$ & $\begin{array}{l}\text { Show internet images of many } \\
\text { species of different plants and } \\
\text { animals. Discuss the meaning of } \\
\text { diversity and how the differences } \\
\text { among things enhance the beauty of } \\
\text { life. } \\
\text { https://youtu.be/e Ne-J9oHTU } \\
\text { Complete page } 47\end{array}$ & \begin{tabular}{|l} 
Observation \\
Worksheet \\
Discussion
\end{tabular} & $\begin{array}{l}\text { Different levels } \\
\text { of discussion } \\
\text { TA assist }\end{array}$ \\
\hline 4 & $\begin{array}{l}\text { Uiversıty, tne spıce ог ॥те } \\
\text { Describe how respect, } \\
\text { empathy and valuing diversity } \\
\text { can positively influence } \\
\text { relationships (ACPPSO37). }\end{array}$ & $\begin{array}{l}\text { Austrailan curriculum } \\
\text { Health Year } 4 \text { book } \\
\text { (p49) } \\
\text { Online links }\end{array}$ & $\begin{array}{l}\text { Llass aıscussıon in cırcie tıme. } \\
\text { Teacher to ask a question to show } \\
\text { how different we are e.g. favourite } \\
\text { food, what sport is your favourite. } \\
\text { Around a photo of themselves, } \\
\text { children fill in information about } \\
\text { themselves. } \\
\text { Use for display }\end{array}$ & $\begin{array}{l}\text { UDservation } \\
\text { Worksheet } \\
\text { Discussion }\end{array}$ & $\begin{array}{l}\text { Uirrerent ievels } \\
\text { of discussion } \\
\text { TA assist }\end{array}$ \\
\hline 5 & \begin{tabular}{|l|} 
Different shades of \\
bullying \\
Describe how respect, \\
empathy and valuing diversity \\
can positively influence \\
relationships (ACPPSO37).
\end{tabular} & $\begin{array}{l}\text { Australian Curriculum } \\
\text { Health Year } 4 \text { book } \\
\text { Online links }\end{array}$ & $\begin{array}{l}\text { What is bullying? } \\
\text { https://youtu.be/39fiuigmL-w } \\
\text { Write students suggestions on the } \\
\text { board - deliberate and repeated } \\
\text { behavior that causes physical or } \\
\text { emotional pain. } \\
\text { What should a person who is being } \\
\text { bullied do? } \\
\text { Discuss the different roles within any } \\
\text { bullying scenario: the bully, person } \\
\text { being bullied, the bully's supporters, } \\
\text { the victim's supporters and the } \\
\text { bystanders. } \\
\text { Discuss things that you can do to } \\
\text { help someone else in the situation: } \\
\text { https://youtu.be/eeqQCyQOCPg } \\
\text { and } \\
\text { https://youtu.be/xdeuivQYnas }\end{array}$ & $\begin{array}{l}\text { Observation } \\
\text { Worksheet } \\
\text { Discussion }\end{array}$ & $\begin{array}{l}\text { Different levels } \\
\text { of discussion } \\
\text { TA assist }\end{array}$ \\
\hline 6 & $\begin{array}{l}\text { Different shades of } \\
\text { bullying } \\
\text { Describe how respect, } \\
\text { empathy and valuing diversity } \\
\text { can positively influence } \\
\text { relationships (ACPPSO37). }\end{array}$ & $\begin{array}{l}\text { Australian Curriculum } \\
\text { Health Year } 4 \text { book } \\
\text { Online links }\end{array}$ & $\begin{array}{l}\text { Look at poster } \\
\text { https://s-media-cache- } \\
\underline{\text { ak0.pinimg.com/originals/b8/dc/b5/ }} \\
\underline{\text { b8dcb5647dfa7b3b10ee1e4ae1ccb8 }} \\
\underline{63 . j p g} \\
\text { Discuss scenarios - is it bullying or } \\
\text { not? Laminate scenarios onto cards } \\
\text { and discuss in groups. }\end{array}$ & $\begin{array}{l}\text { Observation } \\
\text { Worksheet } \\
\text { Discussion }\end{array}$ & $\begin{array}{l}\text { Different levels } \\
\text { of discussion } \\
\text { TA assist }\end{array}$ \\
\hline
\end{tabular}

Figure 1. Health and Physical Education Lesson Plan

Anti-bullying content could be taught in the classroom through age appropriate activities audio visual material, role play debate, discussion, work group where the student can act out roles. Based on the lesson plan above, the teacher gained the video from Youtube as the resources. The video method has been chosen as the easy way for students to understand. Based on the interview with the teacher the video helped the teacher to show the outcome that she wanted to teach for the subject lesson. The video showed the students of diversity, how to respect each other, what is bullying and the effect of bullying.

\section{c. Moral Engagement}

AIS are committed to providing a supportive learning environment that could develop their students' confidence and articulate skills, knowledge, values and attitudes to shape their contribution to the international community. It could be reflected with the value that school includes in every learning activity. The value that is the school concern is moral engagement.

Moral is a norm that has been applied to every individual interaction and thoughtful care of each other. There is a connection between an individual's moral self-view, behavior and behavior positively in a social setting and display 
of sense. Susila (2020) states to develop positive student behavior and eliminate negative student behavior, a teacher need to gives an effective domain assessment and reflected to the student by involves their feeling and shape of behavior in certain period. In AIS, the moral that has concern most is respect. A student who morally engaged may be bothered by mistreatment of the others and find it harder to ignore. Morally engaged individual for school including student, teachers, counselors, parents can influence other through their positive social behavior. Based on the observation, every student from the first step in this school has been emphasizing respect for each other, respect for their teacher, respect for the head of school and respect for their parents and the other families. Their concern of morals may lead them to take action and address the bullying. According to the interview with the Head of school the student in AIS has been understanding that everyone has a different style of learning and could accept the diversity and they have been known that a student is different and can accept the condition.

As an inclusive school, AIS has developed a curriculum to support special-need students with a modified curriculum based on ability specification. The special-need student also will be accompanied with a shadow teacher in their daily activity. In some subjects the special-need student will join in the classroom with the other mainstream as well as in health lessons. Teaching special-need by some teacher will use the method of sample as well as the behavior lesson. The special need will show the expected and unexpected behavior that they need to be understood about behavioral.

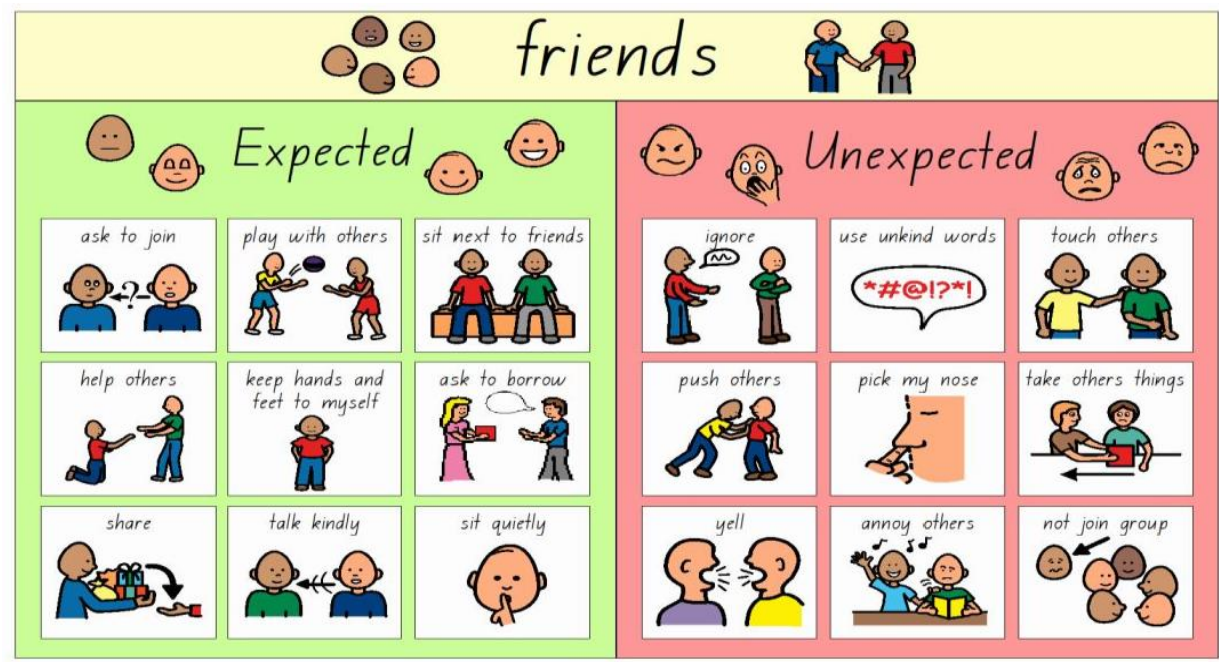

Figure 2. Expected and Unexpected Behavior for Special-need Student

Special students are also being explained about the bullying and given the sample of bullying. The teacher will play a video about bullying explanations, victims and how to handle the bullying. During the class activity, the teacher also applied of an anti-bullying program for mainstream and special-need students and gathered them in a lesson. If there is a student that has said or done something the teacher will separate them in 
sequence. The act could be indicated as the first stage of bullying.

According to Kamaruddin (2012) stated that character is an important part of education performance and school as the institution which is inserting the positive impact to the student in social activities in develop care and respect to the others. The school's role in building student character will be reflected in their everyday behavior. In Australian education the character education is included on the health subject and will introduce the student about wholeness and wellbeing.

\section{d. Promoting Up-stander Behavior}

An up-stander is someone who takes action against bullying behavior. They will help to stop bullying rom happening or support the person who is being bullied. To influence the student and become an up-stander, the teacher has been shown a video about the up-stander program. By stander is a person that does not anything when they see bullying in their eyes. Upstander is a person that reports to someone they trust and helps the victims from bullying. The goals of this lesson are the student will be upstander and speak up on what they are see when bullying happens.

The aim is to promote up-stander behavior by teaching students the skills that will enable them to shift from being passive bystanders to active defenders of bullying situations. The programs should raise the student's awareness and support the person being bullied such as to feel supported and accepted. The teacher and school hoping this program focuses on peer responses to bullying by encouraging students to intervene on students being bullied. According to Barnett, Fisher, O'Connell, and Franco (2019) stated that it is important to empower the student to take action, stop bullying and encourage the bullied students by gather them with the other student to make them feel safe and welcome. The best way to prevent bullying is to become an upstander to bullied, when an upstander sees or hears about someone being bullied, they will speak up and stand for the right do their best to support and protect someone who being hurt.

\section{e. Rewarding}

Assess the student comprehension in character education specially bullying behavior, beside from the health subject as the compulsory lesson the teacher also assess from the student behavior in everyday attitude in up-stander program. According to Arifin in (Natalia, Salim, \& Rasyid, 2014) explained that there are two technique in giving reward by the teacher which is verbal and non-verbal, (1) verbal technique are the reward that giving to the student in the form of encouragement, encouraging that praise the student motivation, (2) nonverbal technique are the reward that could be form in proximity, contact, fun activity and symbols such as certificate and some praises. Students that could show a good attitude will earn some point and every point result will show every morning during circle time. Every month the student will deserve to earn a reward is the form of a certificate which is handed out at the assembly witnessed by their parents 


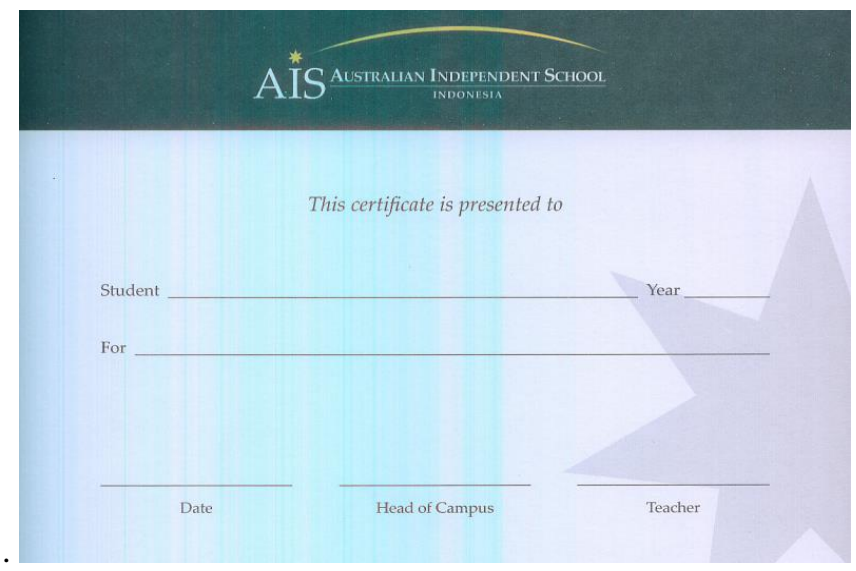

Figure 3. Certificate example

\section{f. Training or Staff}

In order to be effective, the anti-bullying program needs to be extended to whole school support. Whole schools need collaboratively developed structures to support safety and wellbeing. To support the more information about bullying, schools have organized training to the academic staff that everyday deals with the students. According to Mu'izz (2017) stated that a teacher need to continue to improve their competence, renew their mindset and some strategy in develop proper learning programs. Based on the interview with the Head of School, a few years ago they have invited a team from Sue Larkey that have been an expert in handling autism, and it was good training for the staff and improved our information about bullying for special-need students. Most of the staff has been familiar with the characteristics and learning stuff to dealing with special-need students. Clearly communicated procedures for staff to follow when responding to incidents or situations of child violence or bullying. Some training needs to be held to increase the knowledge about bullying sign.

\section{CONCLUSION}

Bullying has been a major concern for the school especially for inclusive school. The teacher has developed a few strategies to prevent bullying happened on the classroom. The teacher has used classroom management by placed some posters of anti-bullying to remain the students about the effect of bullying meanwhile the teacher gathered the mainstream students with the special-need student. The teacher also has involved the moral engagement to raise the character of every student including special-need student. The teacher chooses a promptly and effective learning resources and the student will express their opinion in the form of work sheet.

The teacher has developed modified curriculum by including character education which is the basic behavior for special-need student. To fight back the bullied and support the victims, the teacher also mentions about up-stander behavior to the entire students during the activity. In every behavior that the students shown, the teacher will praise the student and take note on their points. By the end the teacher will award the student with certificate and hand out in the assembly. To improve the teacher knowledge about bullying, the 
school also has been holding a trainee by collaborate with other educational institutions.

\section{REFERENCES}

Arifin, T. (2014). Dampak Tindak Kekerasan (Bullying) Terhadap Perilaku Agresif Siswa. Universitas Islam Negeri Sunan Kalijaga.

Barnett, J. E. H., Fisher, K. W., O'Connell, N., \& Franco, K. (2019). Middle School Journal Promoting Upstander Behavior to Address Bullying in School Research Gate.net, 50(1),

5. doi:https://doi.org/10.1080/00940771.201 $\underline{8.1550377}$

Beane, A. L., PH.D. (2009). Bullying Prevention for Schools a Step-by Step to Implementing a Successful Anti-Bullying Program. San Francisco: JosseyBass.

Desiningrum, D. R. (2016). Psikologi Anak Berkebutuhan Khusus: Psikosain.

Kamaruddin, S. A. (2012). Character Education and Students Social Behavior Journal of Ecuducation and Learning University of Makassar City, 6(4), 7.

Lestari, S., Yusmansyah, \& Mayasari, S. (2018). Bentuk dan Faktor Penyebab Perilaku Bullying. Universitas Lampung.

Mu'izz, M. (2017). Implementasi Pendidikan dan Pelatihan dalam meningkatkan Kompetensi Guru di MTS Negeri 2
Bandar Lampung (Pasca Sarjana), Institut Agama Islam Negeri Raden Intan Lampung, Lampung.

Olwus, D., \& Limber, S. P. (2010). The Olweus Bullying Prevention Program Implementation and Evaluation over Two Decades. Research Gate, 27(2010), 377401.

Padmadewi, N. N., \& Artini, L. P. (2017). Teaching English to a Student with Autism Spectrum Disorder in Regular Classroom in Indonesia. International Journal of Instruction, 10(3), 159-176.

Priantini, D.A.M.M.O. (2021). How Effective is Learning Style Material with Emodules During The COVID-19 Pandemic?. Jurnal IImiah Sekolah Dasar, 5(2). doi:http://dx.doi.org/10.23887/jisd.v5i2.37 687

Putra, N. (2012). Metode Penelitian Kualitatif pendidikan Jakarta: PT. Rajagrafindo Persada

Susila, I. K. (2020). Utilization of Classcraft in Developing Positive Student Behavior. Journal of Education Technology, 510-515.

Usman, \& Dangara, Y. (2016). Educational Resources: An Integral Component for Effective School Administration in Nigeria. Research on Humanities and Social Sciences, 6(13), 10. 